\title{
A systematic review and meta-analysis on Staphylococcus aureus carriage in psoriasis, acne and rosacea
}

\author{
J. E. E. Totté ${ }^{1}$ W. T. van der Feltz ${ }^{2}$ - L. G. M. Bode ${ }^{3}$ A. van Belkum ${ }^{4,5}$ • \\ E. J. van Zuuren ${ }^{6}$ • S. G. M. A. Pasmans ${ }^{1}$
}

Received: 9 April 2016 / Accepted: 9 April 2016/Published online: 5 May 2016

(C) The Author(s) 2016. This article is published with open access at Springerlink.com

\begin{abstract}
Staphylococcus aureus might amplify symptoms in chronic inflammatory skin diseases. This study evaluates skin and mucosal colonization with $S$. aureus in patients with psoriasis, acne and rosacea. A systematic literature search was conducted. Both odds ratios (OR) for colonization in patients versus controls and the prevalence of colonization in patients are reported. Fifteen articles about psoriasis and 13 about acne (12 having a control group) were included. No study in rosacea met our inclusion criteria. For psoriasis, one study out of three controlled studies showed increased skin colonization (OR 18.86; $95 \%$ confidence interval [CI] 2.20-161.99). Three out of the five studies that reported on nasal colonization showed significant ORs varying from 1.73 (95\% CI $1.16-2.58)$ to 14.64 (95\% CI 2.82-75.95). For acne one of
\end{abstract}

Electronic supplementary material The online version of this article (doi:10.1007/s10096-016-2647-3) contains supplementary material, which is available to authorized users.

J. E. E. Totté

j.totte@erasmusmc.nl

1 Department of Dermatology, Erasmus MC University Medical Center, Rotterdam, The Netherlands

2 Molecular and Cellular Life Sciences, Utrecht University, Utrecht, The Netherlands

3 Department of Medical Microbiology, University Medical Center Utrecht, Utrecht, The Netherlands

4 bioMérieux, Scientific Office, La Balme Les Grottes, France

5 Department of Medical Microbiology and Infectious Diseases, Erasmus MC University Medical Center,

Rotterdam, The Netherlands

6 Department of Dermatology, Leiden University Medical Center, Leiden, The Netherlands the three studies that evaluated skin colonization reported a significant OR of 4.16 (95\% CI 1.74-9.94). A relation between nasal colonization and acne was not found. Limitations in study design and low sample sizes should be taken into consideration when interpreting the results. Colonisation with S. aureus seems to be increased in patients with psoriasis. This bacterial species, known for its potential to induce long-lasting inflammation, might be involved in psoriasis pathogenesis. Information on acne is limited. Prospective controlled studies should further investigate the role of $S$. aureus in chronic inflammatory skin diseases.

\section{Introduction}

The inflammatory skin disorders atopic dermatitis, psoriasis, acne and rosacea have been associated with imbalances of the skin microbiome [1-4]. Local expansion of microbes with enhanced inflammatory potential, such as Staphylococcus aureus, was described as a potential mechanism for (secondary) inflammation in skin diseases [1]. In atopic dermatitis, patients are more likely to be colonized with $S$. aureus than healthy controls and colonization increases with AD severity [5]. Recent studies suggest that $S$. aureus contributes to long-lasting cutaneous inflammation in $\mathrm{AD}$ via binding to Toll-like receptor (TLR) 2 and local immunosuppression favoring prolonged colonization. This raises the question whether $S$. aureus might also play a role in other chronic inflammatory skin conditions, such as psoriasis, acne and rosacea [6].

Current research into the microbial pathogenesis of psoriasis focusses mainly on Streptococci. Propionibacterium acnes is most described in acne and Demodex mites are linked to rosacea [7-10]. However, the exact role of these microbes in the diseases is debated. In psoriasis, lesional 
skin is enriched in Streptococcus spp. [11]. However, evidence for the induction of the disease by a preceding streptococcal infection exist only for the subtype of guttate psoriasis [12]. S. aureus has been linked to exacerbations in psoriasis $[7,13]$. It can activate Th1 and Th17 cells, promoting the production of interleukins TNF- $\alpha$ and IFN- $\gamma$ which perpetuates keratinocyte damage [14-18]. Furthermore, staphylococcal enterotoxins can activate $\mathrm{T}$ cells inducing a more systemic immunological response, and staphylococcal peptidoglycan can favour proliferation of keratinocytes [19-22].

In acne, Propionibacterium acnes probably contributes to inflammation via stimulation of TLR2 [23-26]. However, certain strains rather than the entire species seem to be involved and the association between colonization and acne symptoms has been contested [27-29]. Chitin released from Demodex mites is thought to stimulate TLR2 receptors in rosacea $[8,9,30,31]$. A role for $S$. aureus in acne and rosacea can be hypothesized based on $S$. aureus' ability to stimulate TLR2, for example via alpha toxin [32-34].

Currently, antibiotics are part of standard therapy against acne and rosacea. Antibiotics often display broad spectrum activity which could damage the skin [35-37]. Furthermore, resistance against antibiotics is increasing, putting pressure on the (maintenance) treatment of inflammatory skin diseases [38-41]. In the development of new antimicrobial therapies, targeted treatment directed against a single bacterial species is gaining in importance [42]. In order to determine the scope of these new therapeutics we have to understand which specific microbes play a role in diseases. Investigating the abundance of $S$. aureus in a disease-specific ecosystem might give more insight in its possible role in pathogenesis. This systematic review and meta-analysis evaluates colonization of the skin and mucosa with $S$. aureus in patients with psoriasis, acne and rosacea compared with healthy controls.

\section{Materials and methods}

\section{Type of study}

Original experimental and observational (human) studies were included. Case reports were excluded. No restrictions were made as to publication date and language.

\section{Type of participants}

Studies conducted in patients with psoriasis, acne or rosacea as diagnosed by a physician, were included. No restriction was made as to age of the patients.

\section{Type of outcome measures}

The primary outcomes were proportion of patients with presence of $S$. aureus on the skin, nares or pharynx and the odds for colonization compared with healthy controls. The secondary outcome was presence of $S$. aureus virulence factors on the skin or encoded in the bacterial genome. In case of intervention studies, both pre- and post treatment measurements were included in this review, but only the baseline measurement was included in the meta-analysis. When studies reported multiple measurements over time taken from the same skin site (without treatment regimen) or when multiple locations were sampled at the same time point, the mean was included in the meta-analysis. Articles that reported combined results of different sample locations were excluded.

\section{Search strategy}

The search was conducted in Embase, Medline, Ovid-SP, Pubmed, Web of Science and the Cochrane Central Database from inception to September 2014 (Table S1). A cross reference check was performed to identify further relevant studies.

\section{Study selection and data extraction}

The titles and abstracts were screened for relevance and selected on the basis of the in- and exclusion criteria. The quality of the articles was rated using an extended version of the Newcastle Ottawa Scale (NOS) (Supplementary material) $[43,44]$. Uncontrolled studies could reach a maximum score of 7 points for study quality on the NOS. Studies including a control group could reach a maximum score of 8 . Using a scoring algorithm (Supplementary material), the controlled articles were classified as being of poor, fair or good quality [45]. Study selection and quality assessment were performed independently by two researchers (JT and WF). Disagreements were discussed and resolved. If identical populations were described in different publications (co-publication of same study), the study providing the most data was included.

\section{Statistical analysis}

A weighted prevalence of colonization with $S$. aureus in the nose and/or skin was calculated. In controlled studies, the prevalence of colonization was compared between patients and controls and expressed as an odds ratio with a $95 \%$ confidence interval. If possible, a meta-analysis was carried out using a random-effects model. Only studies in which patients were not receiving treatment were included for meta-analysis. Heterogeneity was assessed using the $\mathrm{I}^{2}$ statistic. If heterogeneity was $<80 \%$, data were pooled. The low number of studies did not permit an assessment of publication bias using 
funnel plots and Egger's regression [46]. All statistical analyses were performed using Comprehensive Meta-Analysis Version 2.2 (Biostat, Englewood, NJ). This systematic review was conducted and reported in accordance with the PRISMA guidelines [47].

\section{Results}

\section{Study characteristics}

The search yielded a total of 3,791 articles. After deduplication 2,343 articles remained. Based on title and abstract we identified 51 references on psoriasis, 52 on acne and seven on rosacea (Fig. 1). Twenty-eight references, 15 about psoriasis and 13 about acne, met our inclusion criteria after reading the full text. All studies had an observational study design. No study in patients with rosacea met our inclusion criteria. Methods to collect and identify S. aureus and study characteristics are described in Table S2a and S2b.

\section{Quality of the studies}

We rated the quality of the included articles with a control group as fair $(n=6)$ and poor $(n=6)$. The quality of the uncontrolled studies varied from 0 to 6 points of 7 on the NOS. Table S3a and S2b describe the NOS scores per study. The main reason for downgrading the quality of controlled studies was incomparability of the patient and control groups. Reasons for downgrading the uncontrolled studies were limited description of the methods used for collection of bacteria and identification of $S$. aureus. Low NOS scores are also partly due to inclusion of abstracts, describing limited information on methods. Selection bias might have occurred as the studies included in the review often concern a very specific disease population (treated mostly in tertiary centres). Furthermore, the impact of exposures such as treatment regimen at the moment of collection was poorly reported, which might have resulted in performance bias.

\section{Colonization with S. aureus of skin and mucosae in psoriasis}

Eight of the 15 studies about psoriasis examined S. aureus on lesional skin. The proportion of patients with $S$. aureus on lesional skin varied from 0.03 (95\% CI $0.02-0.06)$ to 0.64 ( $95 \%$ CI $0.50-0.76$ ) (Table 1). Three of these studies included a control group and one showed a significant increase of colonization of the skin in patients compared to controls (odds ratio [OR] 18.86; $95 \%$ CI 2.20-161.99).
Fig. 1 Flow chart of search strategy and study selection

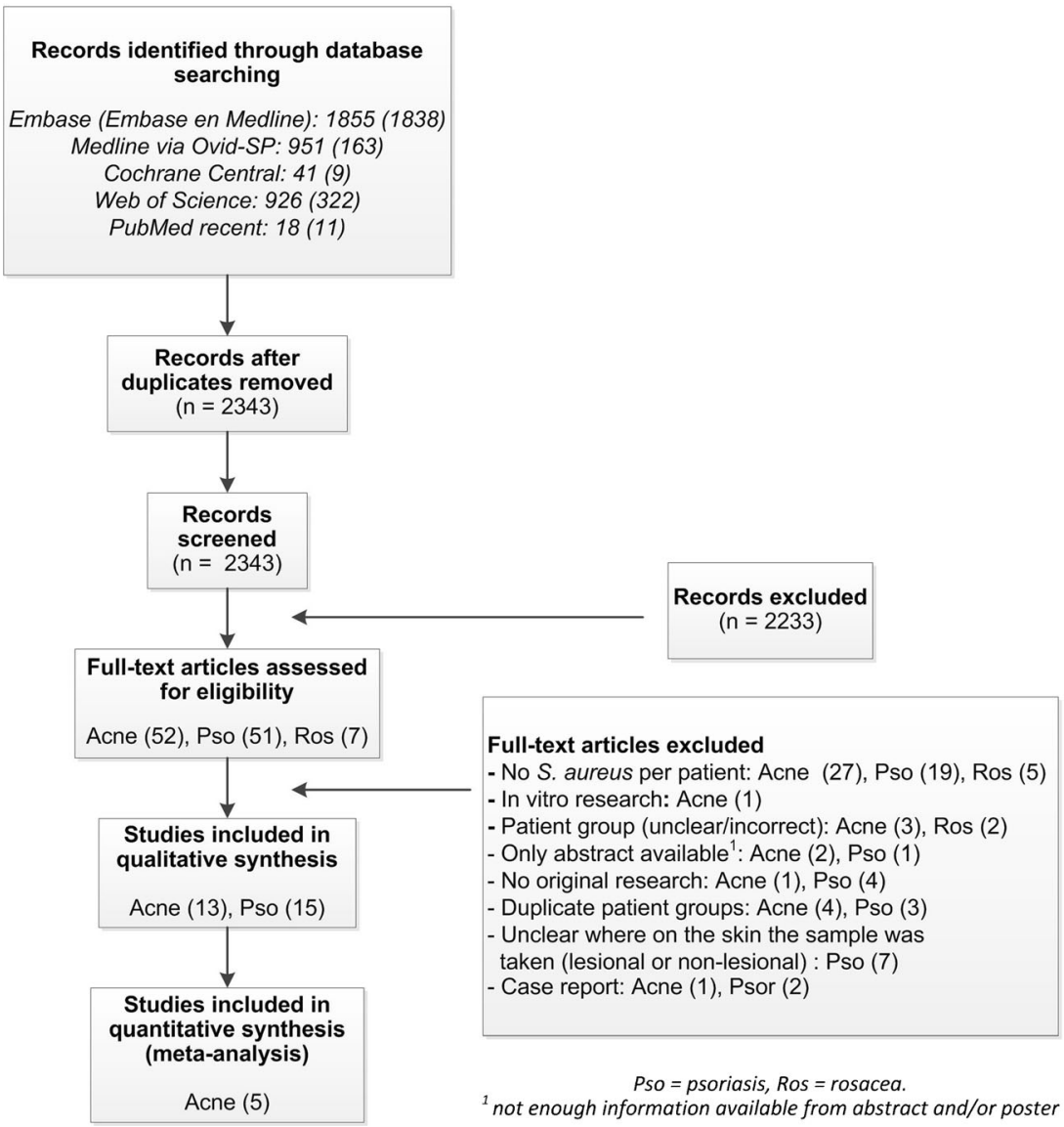


Table 1 Event rates and odds ratios of skin colonization with S. aureus in psoriatic patients and controls

\begin{tabular}{|c|c|c|c|c|c|c|c|}
\hline \multirow{2}{*}{\multicolumn{2}{|c|}{ Author }} & \multicolumn{3}{|l|}{ Patients } & \multicolumn{2}{|l|}{ Controls } & \multirow[t]{2}{*}{ Odds ratio $(95 \% \mathrm{CI})$} \\
\hline & & $\begin{array}{l}\text { Sample } \\
\text { size }\end{array}$ & $\begin{array}{l}\text { Event rate } \\
\text { colonization } \\
\text { lesional skin } \\
(95 \% \mathrm{CI})\end{array}$ & $\begin{array}{l}\text { Event rate } \\
\text { colonization non- } \\
\text { lesional skin } \\
(95 \% \mathrm{CI})\end{array}$ & $\begin{array}{l}\text { Sample } \\
\text { size }\end{array}$ & $\begin{array}{l}\text { Event rate } \\
\text { colonization } \\
\text { skin } \\
(95 \% \mathrm{CI})\end{array}$ & \\
\hline \multicolumn{2}{|l|}{ Atefi et al. 2012 [19] } & 40 & $0.08(0.02-0.21)$ & & 40 & $0.03(0.00-0.16)$ & $3.16(0.32-31.78)$ \\
\hline \multicolumn{2}{|c|}{ Tabatabaei et al. 2011 [48] } & 50 & & $0.06(0.02-0.17)$ & 50 & $0.02(0.00-0.13)$ & $3.13(0.31-31.14)$ \\
\hline \multicolumn{2}{|l|}{ Balci et al. 2009 [13] } & 50 & $0.64(0.50-0.76)$ & $0.14(0.07-0.27)$ & & & \\
\hline \multicolumn{2}{|l|}{ Tomi et al. 2005 [49] } & 25 & $0.44(0.26-0.63)$ & & 25 & $0.04(0.01-0.24)$ & $18.86(2.20-161.99)$ \\
\hline \multicolumn{2}{|l|}{ Ryu et al. 2003 [50] } & 22 & $0.45(0.26-0.65)$ & $0.33(0.17-0.55)^{\mathrm{a}}$ & 25 & $0.32(0.17-0.52)$ & $\begin{array}{l}\text { Lesional skin } 1.74 \\
\quad(0.53-5.70) \\
\text { Non-lesional } 1.04 \\
(0.31-3.56)\end{array}$ \\
\hline \multicolumn{2}{|l|}{ Brook et al. 1999 [51] } & 28 & $0.54(0.35-0.71)$ & & & & \\
\hline \multicolumn{2}{|l|}{ Sayama et al. 1998 [52] } & 100 & $0.15(0.09-0.23)$ & $0.06(0.02-0.13)^{\mathrm{b}}$ & & & \\
\hline \multirow[t]{8}{*}{ Noah et al. 1990 [53] } & Overall $^{\mathrm{c}}$ & 297 & $0.03(0.02-0.06)$ & & & & \\
\hline & Axilla & 297 & $0.01(0.00-0.03)$ & & & & \\
\hline & Submammary & 297 & $0.01(0.00-0.03)$ & & & & \\
\hline & Umbilical & 297 & $0.02(0.01-0.05)$ & & & & \\
\hline & Inguinal & 297 & $0.02(0.01-0.05)$ & & & & \\
\hline & Gluteal & 297 & $0.10(0.07-0.14)$ & & & & \\
\hline & Vaginal & 297 & $0.03(0.01-0.05)$ & & & & \\
\hline & Penis-scrotal & 297 & $0.04(0.02-0.07)$ & & & & \\
\hline \multirow{5}{*}{$\begin{array}{l}\text { Weissmann et al. } \\
1980 \text { [54] }\end{array}$} & Overall $^{\mathrm{d}}$ & 10 & & $0.55(0.42-0.67)$ & & & \\
\hline & Arm before treatment & 10 & & $0.50(0.22-0.78)$ & & & \\
\hline & Back before treatment & 10 & & $0.60(0.30-0.84)$ & & & \\
\hline & Arm after treatment & 10 & & $0.40(0.16-0.70)$ & & & \\
\hline & Back after treatment & 9 & & $0.33(0.11-0.66)$ & & & \\
\hline \multicolumn{2}{|l|}{ Aly et al. 1976 [55] } & 40 & $0.20(0.10-0.35)$ & $0.13(0.05-0.27)$ & & & \\
\hline
\end{tabular}

a Sample size is 21

b Sample size is 89

c Average event rate of the different locations on the skin

d Average event rate of multiple locations on the skin before treatment

Non-lesional skin was examined in six studies. The prevalence of patients with colonization varied between 0.06 (95\% CI 0.02-0.13) and 0.55 (95\% CI 0.42-0.67) (Table 1). The two studies that included a control group did not find a statistically significant difference in colonization between psoriatic patients and healthy controls (Tabatabaei 2011; OR 3.13; $95 \%$ CI $0.31-31.14$ and Ryu 2003; OR 1.04; $95 \%$ CI $0.31-3.56)[48,50]$.

Seven studies evaluated nasal colonization with the proportion of patients with nasal colonization varying from 0.27 (95\% CI $0.13-0.49)$ to 0.76 (95\% CI $0.62-0.86)$ (Table 2). Five studies included a control group of which three reported a statistically significant increased nasal colonization rate in patients with psoriasis compared to healthy controls. ORs varied from 1.73 (95\% CI 1.16$2.58)$ to 14.64 (95\% CI 2.82-75.95) (Table 2).
A meta-analysis was not performed as the treatment regimen was not adequately described or differed between the studies.

Three studies measured $S$. aureus colonization in the pharynx. The proportion of patients with pharyngeal colonization was 0.04 (95\% CI 0.03-0.07) (Noah 1990), 0.50 (95\% CI $0.30-0.70)$ (Ajib 2005) and 0.20 (95\% CI 0.13-0.29) (Sayama 1998)) [52, 53, 59]. The presence of $S$. aureus toxins was investigated in seven studies. An overview of the results of these studies can be found in Table S4. Balci et al. concluded that psoriatic patients were colonized with toxigenic strains more frequent than controls $(p=0.006)$ [13]. Ajib et al. and Tabatabaei et al. also show data that support a role of toxins in lesions but no statistically significant difference between patients and controls was reported $[48,59]$. Tomi et al. found a statistically significant relation between a higher Psoriasis 
Table 2 Event rates and odds ratios of nasal colonization with $S$. aureus in psoriatic patients and controls

\begin{tabular}{|c|c|c|c|c|c|}
\hline \multirow[t]{2}{*}{ Author } & \multicolumn{2}{|l|}{ Patients } & \multicolumn{2}{|l|}{ Controls } & \multirow{2}{*}{$\begin{array}{l}\text { Odds ratio } \\
(95 \% \mathrm{CI})\end{array}$} \\
\hline & $\begin{array}{l}\text { Sample } \\
\text { size }\end{array}$ & $\begin{array}{l}\text { Event rate of nasal } \\
\text { colonization } \\
(95 \% \mathrm{CI})\end{array}$ & $\begin{array}{l}\text { Sample } \\
\text { size }\end{array}$ & $\begin{array}{l}\text { Event rate of nasal } \\
\text { colonization } \\
(95 \% \mathrm{CI})\end{array}$ & \\
\hline $\begin{array}{l}\text { Andersen et al. } 2013 \\
\text { [56] }\end{array}$ & 112 & $0.36(0.28-0.45)$ & 1985 & Not mentioned & $1.73(1.16-2.58)$ \\
\hline Balci et al. 2009 [13] & 50 & $0.50(0.36-0.64)$ & 50 & $0.34(0.22-0.48)$ & $1.94(0.87-4.35)$ \\
\hline Tomi et al. 2005 [49] & 25 & $0.56(0.37-0.74)$ & 25 & $0.08(0.02-0.27)$ & $14.64(2.82-75.95)$ \\
\hline Ryu et al. 2003 [50] & 22 & $0.27(0.13-0.49)$ & 25 & $0.24(0.11-0.44)$ & $1.18(0.32-4.40)$ \\
\hline Klein et al. 1997 [57] & 33 & $0.33(0.19-0.51)$ & & & \\
\hline Singh et al. 1978 [58] & 50 & $0.76(0.62-0.86)$ & 33 & $0.6(0.43-0.75)$ & $2.64(1.03-6.79)$ \\
\hline Aly et al. 1976 [55] & 40 & $0.30(0.18-0.46)$ & & & \\
\hline
\end{tabular}

Area Severity Index (PASI) score and enterotoxin-positive $S$. aureus versus toxin negative $S$. aureus $(\mathrm{p}=0.001)$ [49].

\section{Colonization with $\mathrm{S}$. aureus of skin and mucosae in acne}

Seven of the 13 articles evaluating acne patients reported on lesional skin colonization with $S$. aureus. The proportion of patients with skin colonization varied between 0.01 (95\% CI 0.00-0.07) and 0.54 (95\% CI 0.40-0.67) (Table 3). Three studies compared skin colonization between patients and controls. Only one found a significant OR of 4.16 (95\% CI 1.74-9.94) (Table 3) [60, $62,65]$. Seven studies reported on the prevalence of nasal $S$. aureus colonization (Table 4). Pooled analysis from the

Table 3 Event rates and odds ratios of skin colonization with S. aureus in acne patients and controls

\begin{tabular}{|c|c|c|c|c|c|c|c|}
\hline \multirow{2}{*}{\multicolumn{2}{|c|}{ Author }} & \multicolumn{3}{|l|}{ Patients } & \multicolumn{2}{|l|}{ Controls } & \multirow{2}{*}{$\begin{array}{l}\text { Odds ratio } \\
(95 \% \mathrm{CI})\end{array}$} \\
\hline & & $\begin{array}{l}\text { Sample } \\
\text { size }\end{array}$ & $\begin{array}{l}\text { Event rate of } \\
\text { lesional skin } \\
\text { colonization } \\
(95 \% \mathrm{CI})\end{array}$ & $\begin{array}{l}\text { Event rate of } \\
\text { non-lesional } \\
\text { skin } \\
\text { colonization } \\
(95 \% \mathrm{CI})\end{array}$ & $\begin{array}{l}\text { Sample } \\
\text { size }\end{array}$ & $\begin{array}{l}\text { Event rate skin } \\
\text { colonization } \\
(95 \% \mathrm{CI})\end{array}$ & \\
\hline \multicolumn{2}{|c|}{ Numata et al. 2013 [60] } & 100 & $0.01(0.00-0.07)^{\mathrm{a}}$ & & 100 & $0.01(0.00-0.07)^{\mathrm{a}}$ & \\
\hline \multicolumn{2}{|c|}{ Moon et al. 2012 [61] } & 100 & $0.06(0.03-0.13)$ & & & & \\
\hline \multicolumn{2}{|c|}{ Hassanzadeh et al. 2008 [62] } & 100 & $0.41(0.32-0.51)$ & & 100 & $0.30(0.22-0.40)^{\mathrm{b}}$ & $1.62(0.90-2.91)$ \\
\hline \multirow{6}{*}{$\begin{array}{c}\text { Williams et al. } \\
1992^{\mathrm{c}}[63]\end{array}$} & Before treatment & 28 & $0.02(0.00-0.22)^{\mathrm{a}}$ & & & & \\
\hline & 1 month after start & 28 & $0.14(0.05-0.32)$ & & & & \\
\hline & 2 months after start & 28 & $0.32(0.18-0.51)$ & & & & \\
\hline & 3 months after start & 28 & $0.21(0.10-0.40)$ & & & & \\
\hline & 4 months after start & 28 & $0.25(0.12-0.44)$ & & & & \\
\hline & 5 months after start & 28 & $0.02(0.00-0.22)^{\mathrm{a}}$ & & & & \\
\hline \multirow{2}{*}{$\begin{array}{l}\text { Al Mishari et al. } \\
1987^{\mathrm{d}}[35]\end{array}$} & Before treatment & 20 & $0.05(0.01-0.28)$ & $0.05(0.01-0.28)$ & & & \\
\hline & 4 months after start & 20 & $0.02(0.00-0.29)^{\mathrm{a}}$ & & & & \\
\hline \multirow{3}{*}{$\begin{array}{l}\text { Leyden et al. } \\
\qquad 1986^{\mathrm{e}}[64]\end{array}$} & Before treatment & 40 & $0.03(0.00-0.16)$ & & & & \\
\hline & 1 month after start & 40 & $0.15(0.07-0.30)$ & & & & \\
\hline & 5 months after start & 40 & $0.50(0.35-0.65)$ & & & & \\
\hline \multirow{2}{*}{$\begin{array}{r}\text { Batova et al. } \\
1971 \text { [65] }\end{array}$} & Swab without buffer & 40 & $0.15(0.07-0.30)$ & & & & \\
\hline & Swab with buffer & 50 & $0.54(0.40-0.67)$ & & 50 & $0.22(0.13-0.36)$ & $4.16(1.74-9.94)$ \\
\hline \multicolumn{8}{|c|}{${ }^{\mathrm{a}}$ Event rate $=0.00(\mathrm{OR}$ not calculated $)$} \\
\hline \multicolumn{8}{|c|}{${ }^{b}$ Healthy skin of patients is used as a control } \\
\hline \multicolumn{8}{|c|}{${ }^{\mathrm{c}}$ Patients were treated with isotretinoin for 4 months } \\
\hline \multicolumn{8}{|c|}{${ }^{\mathrm{d}}$ Patients were treated with tetracycline for 4 months } \\
\hline \multicolumn{8}{|c|}{${ }^{\mathrm{e}}$ Patients were treated with isotretinoin for 5 months } \\
\hline
\end{tabular}


Table 4 Event rates and odds ratios of nasal colonization with $S$. aureus in patients with acne patients and controls

\begin{tabular}{|c|c|c|c|c|c|c|}
\hline \multirow[t]{2}{*}{ Author } & & \multicolumn{2}{|l|}{ Patients } & \multicolumn{2}{|l|}{ Controls } & \multirow[t]{2}{*}{ Odds ratio } \\
\hline & & Sample size & $\begin{array}{l}\text { Event rate of nasal } \\
\text { colonization }(95 \% \mathrm{CI})\end{array}$ & Sample size & $\begin{array}{l}\text { Event rate of nasal } \\
\text { colonization }(95 \% \mathrm{CI})\end{array}$ & \\
\hline \multirow[t]{2}{*}{ Ozuguz et al. 2014 ${ }^{\mathrm{a}}[66]$} & Before treatment & 55 & $0.01(0.00-0.13)^{\mathrm{e}}$ & 20 & $0.02(0.01-0.29)^{\mathrm{e}}$ & \\
\hline & 3 months after start & 55 & $0.09(0.04-0.20)$ & & & \\
\hline \multirow[t]{2}{*}{ Basak et al. 2013 ${ }^{\mathrm{b}}[67]$} & Before treatment & 35 & $0.09(0.03-0.23)$ & & & \\
\hline & After treatment & 35 & $0.40(0.25-0.57)$ & & & \\
\hline Toyne et al. 2012 [68] & & 116 & $0.26(0.19-0.35)$ & & & \\
\hline Khorvash et al. 2012 [69] & & 166 & $0.22(0.16-0.29)$ & 158 & $0.27(0.20-0.34)$ & $0.77(0.46-1.29)$ \\
\hline Fanelli et al. 2011 [70] & & 83 & $0.19(0.12-0.29)$ & & & \\
\hline \multirow[t]{6}{*}{ Williams et al. $1992^{\mathrm{c}}$ [63] } & Before treatment & 28 & $0.11(0.03-0.28)$ & & & \\
\hline & 1 month after start & 28 & $0.32(0.18-0.51)$ & & & \\
\hline & 2 months after start & 28 & $0.57(0.39-0.74)$ & & & \\
\hline & 3 months after start & 28 & $0.46(0.29-0.64)$ & & & \\
\hline & 4 months after start & 28 & $0.32(0.18-0.51)$ & & & \\
\hline & 5 months after start & 28 & $0.43(0.26-0.61)$ & & & \\
\hline \multirow[t]{3}{*}{ Leyden et al. $1986^{\mathrm{d}}[64]$} & Before treatment & 40 & $0.03(0.00-0.16)$ & & & \\
\hline & 1 months after start & 40 & $0.30(0.18-0.46)$ & & & \\
\hline & 5 months after start & 40 & $0.70(0.54-0.82)$ & & & \\
\hline
\end{tabular}

${ }^{\text {a }}$ Twenty patients were treated with oral antibiotics, 20 with isotretinoin, 15 patients received no treatment

b Twenty patients were treated with isotretinoin for an unknown duration

${ }^{c}$ Patients were treated with isotretinoin for 4 months

${ }^{\mathrm{d}}$ Patients were treated with isotretinoin for 5 months

${ }^{\mathrm{e}}$ Event rate $=0.00$ (OR not calculated)

five studies in which patients were not on antimicrobial treatment (324 patients) showed a nasal colonization rate of 0.08 (95\% CI 0.03-0.20) (Fig. 2). With an $\mathrm{I}^{2}$ of $71 \%$, heterogeneity was considered to be moderate. Two studies included a control group but did not demonstrate a statistically significant difference in $S$. aureus nasal colonization rates between patients and healthy controls [66, 69]. Basak et al., Fanelli et al. and Levy et al. found pharyngeal colonization rates of $0.09,0.33$ and 0.26 , respectively [67, 70, $71]$. No studies reported on the relation between severity of acne and colonization with $S$. aureus or presence of S. aureus virulence factors.

\section{Discussion}

In this systematic review 28 observational studies comprising 1,880 patients were included to evaluate skin and mucosal colonization in patients with psoriasis, acne and rosacea. Patients with psoriasis seem to be colonized with $S$. aureus in the nose more often than healthy controls. One study shows an increased risk of skin colonization in patients compared with controls. However, the sample size of this study was rather small $(n=25)$ [49]. The literature about virulence factors in psoriatic patients versus controls is ambiguous. Only one study reported about disease severity in relation to
Fig. 2 Forest plot of studies reporting proportions of acne patients with nasal $S$. aureus colonization receiving no treatment at the time of sampling. $\mathrm{I}^{2}=71$

\begin{tabular}{|c|c|c|c|c|}
\hline \multirow[t]{3}{*}{ Study name } & \multicolumn{4}{|c|}{ Sample size } \\
\hline & & \multicolumn{3}{|c|}{ Event Lower Upper } \\
\hline & & rate & $\operatorname{limi}$ & limit \\
\hline Ozuguz 2014 & 55 & 0.01 & 0.00 & 0.13 \\
\hline Basak 2013 & 35 & 0.09 & 0.03 & 0.23 \\
\hline Khorvash 2012 & 166 & 0.22 & 0.16 & 0.29 \\
\hline Williams 1992 & 28 & 0.11 & 0.03 & 0.28 \\
\hline Leyden 1986 & 40 & 0.03 & 0.00 & 0.16 \\
\hline & & 0.08 & 0.03 & \\
\hline
\end{tabular}

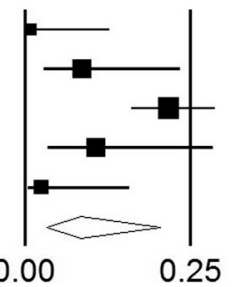

\section{Event rate and $95 \% \mathrm{Cl}$} 0.25 
S. aureus and found a statistically significant relation between a higher PASI score and enterotoxin-positive $S$. aureus versus toxin negative $S$. aureus. In studies on acne, an association between skin colonization and the disease was only found in one of the three articles and therefore less evident $[60,62,65]$. In almost one tenth of the patients with acne $S$. aureus was present in the nose. This is low compared with the nasal colonization rate of healthy people (around $25 \%$ ) [72]. Although the patients included in the meta-analysis did not use treatment at the time of sampling, the low colonization rates might be due to a long-term effect of former use of antibiotics [70,71]. Two studies compared nasal colonization in acne patients with healthy controls and found no statistically significant difference. It has to be noted that in all of these studies there were only few discussions on whether the presence of $S$. aureus represented clear colonization or whether the bacteria were causal agents of pathogenicity. No studies could be included that assessed S. aureus colonization in patients with rosacea. Also in current review literature $S$. aureus is not implicated in the pathophysiology of rosacea [9]. Limitations in study design, such as incomparability of patient and control groups, as well as indirectness and imprecision due to low sample sizes, rate the quality of the evidence down and should be taken in consideration when interpreting the results. Essential information about factors that influence microbiota such as treatment regimen, the exact skin site where a sample was taken and duration of the disease which might influence the antimicrobial effect of the host immune response, was often missing. This hampered our ability to draw conclusions about the bacterial ecology of the skin [73-75].

Few studies performed a pre- and post treatment analysis of S. aureus abundance. Weissmann et al. described a decrease in the percentage of colonized psoriasis patients from $55 \%$ to $36 \%$ after PUVA (photochemotherapy) [54]. Three studies reported an increase of $S$. aureus colonization of nose, oropharynx and skin after isotretinoin therapy for acne (of which one was statistically significant), whereas Ozuguz et al. found no change [63, 64, 66, 67]. In cross-sectional studies Fanelli et al. and Levy et al. demonstrated that antibiotic use decreased the prevalence of $S$. aureus nasal and oropharyngeal colonization $[70,71]$. However, an increase of $S$. aureus colonization was seen after tetracycline therapy in Ozuguz et al [66]. None of the above-mentioned studies reported on the relation between changes in $S$. aureus density and clinical symptoms which could give important information with respect to $S$. aureus causality.

This review has some limitations. Determining the prevalence of $S$. aureus colonization was not the primary objective in a substantial part of the studies. Therefore, indirectness of the evidence with regard to the population might have occurred. Some studies comprised small sample sizes resulting in effect estimates with wide confidence intervals. Controlled studies did not adjust for confounders, such as age, which might influence the given odds ratio. There is a possibility of publication bias as only published studies were considered and as literature focuses on just a few of the many toxins that $S$. aureus produces, this review provides a limited insight on the correlation between toxins of $S$. aureus and psoriasis and acne.

Future research should have a more longitudinal character and focus on bacteria as part of an ecosystem related to severity. This might give more insight in the cause-consequence relation between microorganisms and disease. It is important to consider that the capacity of a microbe to promote disease also depends on other factors such as the host's genetic predisposition, skin barrier integrity and the coexistence of other microbes. As $S$. aureus is common at all depths of the skin, biopsies might be of additional value next to the techniques that evaluate the superficial skin [76]. Molecular approaches to analyse these samples will give a more complete picture of the microbial diversity facilitating the evaluation of low abundance species and their influence $[37,74]$.

This systematic review summarises all available data on $S$. aureus colonization and the presence of virulence factors on the skin and mucosa of patients with psoriasis and acne. Patients with psoriasis seem to be colonized with $S$. aureus more often than healthy controls. The overabundant $S$. aureus in the microbiome of psoriasis patients might play a role in perpetuating chronic inflammation. For patients with acne a relation between colonization and the disease was less evident and for rosacea no information about colonization could be obtained from the literature. Determining the presence of individual bacterial species with inflammatory potential, including $S$. aureus, in patients compared with controls is a first step towards elucidating their possible role in skin diseases and might lead to new options for more targeted antimicrobial therapy.

Acknowledgments We thank G.B. de Jonge (MSc), biomedical information specialist, for her assistance in the electronic literature search.

\section{Compliance with ethical standards}

Funding statement and conflict of interest The Department of Dermatology of the Erasmus MC University Medical Centre Rotterdam received an unrestricted grant from Micreos Human Health, The Netherlands. A. van Belkum is an employee of bioMerieux, a company developing and selling infectious disease' diagnostics; the company had no influence on the design and execution of the present study. W. van der Feltz is a former employee of Micreos Human Health.

Open Access This article is distributed under the terms of the Creative Commons Attribution 4.0 International License (http:// creativecommons.org/licenses/by/4.0/), which permits unrestricted use, distribution, and reproduction in any medium, provided you give appropriate credit to the original author(s) and the source, provide a link to the Creative Commons license, and indicate if changes were made. 


\section{References}

1. Belkaid Y, Segre JA (2014) Dialogue between skin microbiota and immunity. Science 346(6212):954-959

2. Chen YE, Tsao H (2013) The skin microbiome: Current perspectives and future challenges. J Am Acad Dermatol 69(1):143-155

3. Sanford JA, Gallo RL (2013) Functions of the skin microbiota in health and disease. Semin Immunol 25(5):370-377

4. Kong HH, Segre JA (2012) Skin microbiome: looking back to move forward. J Invest Dermatol 132(3 Pt 2):933-939

5. Totte JE, van der Feltz WT, Hennekam M, van Belkum A, van Zuuren EJ, Pasmans SG (2016) Prevalence and odds of Staphylococcus aureus carriage in atopic dermatitis: a systematic review and meta-analysis. Br J Dermatol

6. Biedermann T, Skabytska Y, Kaesler S, Volz T (2015) Regulation of T Cell Immunity in Atopic Dermatitis by Microbes: The Yin and Yang of Cutaneous Inflammation. Front Immunol 6:353

7. Fry L, Baker BS (2007) Triggering psoriasis: the role of infections and medications. Clin Dermatol 25(6):606-615

8. Holmes AD (2013) Potential role of microorganisms in the pathogenesis of rosacea. J Am Acad Dermatol 69(6):1025-1032

9. Steinhoff M, Schauber J, Leyden JJ (2013) New insights into rosacea pathophysiology: a review of recent findings. J Am Acad Dermatol 69(6 Suppl 1):S15-26

10. Gollnick HPM (2015) From new findings in acne pathogenesis to new approaches in treatment. J Eur Acad Dermatol Venereol 29:1-7

11. Gao Z, Tseng CH, Strober BE, Pei Z, Blaser MJ (2008) Substantial alterations of the cutaneous bacterial biota in psoriatic lesions. PLoS One 3(7):e2719

12. Owen CM, Chalmers RJ, O'Sullivan T, Griffiths CE (2001) A systematic review of antistreptococcal interventions for guttate and chronic plaque psoriasis. Br J Dermatol 145(6):886-890

13. Balci DD, Duran N, Ozer B, Gunesacar R, Onlen Y, Yenin JZ (2009) High prevalence of Staphylococcus aureus cultivation and superantigen production in patients with psoriasis. Eur J Dermatol 19(3):238-242

14. Chong HT, Kopecki Z, Cowin AJ (2013) Lifting the silver flakes: the pathogenesis and management of chronic plaque psoriasis. Biomed Res Int 2013:168321

15. Johannessen M, Sollid JE, Hanssen AM (2012) Host- and microbe determinants that may influence the success of S. aureus colonization. Front Cell Infect Microbiol 2:56

16. Lynde CW, Poulin Y, Vender R, Bourcier M, Khalil S (2014) Interleukin 17A: toward a new understanding of psoriasis pathogenesis. J Am Acad Dermatol 71(1):141-150

17. Mahajan R, Handa S (2013) Pathophysiology of psoriasis. Indian J Dermatol Venereol Leprol 79(Suppl 7):S1-9

18. van den Berg WB, McInnes IB (2013) Th17 cells and IL-17 afocus on immunopathogenesis and immunotherapeutics. Semin Arthritis Rheum 43(2):158-170

19. Atefi N, Tabaie M, Noorbakhsh S, Tabatabaie A, Rezaee M, Rohaninasab M (2012) The role of staphylococcus superantigens in chronic plaque type psoriasis. Iran J Dermatol 15(59):1-3

20. Leung DY, Walsh P, Giorno R, Norris DA (1993) A potential role for superantigens in the pathogenesis of psoriasis. J Invest Dermatol 100(3):225-228

21. Yamamoto T, Katayama I, Nishioka K (1998) Clinical analysis of staphylococcal superantigen hyper-reactive patients with psoriasis vulgaris. Eur J Dermatol 8(5):325-329

22. Vazquez-Sanchez EA, Rodriguez-Romero M, Sanchez-Torres LE, Rodriguez-Martinez S, Cancino-Diaz JC, Rodriguez-Cortes O, Garcia-Lopez ES, Cancino-Diaz ME (2014) Peptidoglycan from Staphylococcus aureus has an anti-apoptotic effect in HaCaT keratinocytes mediated by the production of the cellular inhibitor of apoptosis protein-2. Microbiol Immunol 58(2):87-95
23. Bakry OA, Samaka RM, Sebika H, Seleit I (2014) Toll-like receptor 2 and P. acnes: do they trigger initial acne vulgaris lesions? Anal Quant Cytopathol Histpathol 36(2):100-110

24. Beylot C, Auffret N, Poli F, Claudel JP, Leccia MT, Del Giudice P, Dreno B (2014) Propionibacterium acnes: An update on its role in the pathogenesis of acne. J Eur Acad Dermatol Venereol 28(3):271278

25. Jugeau S, Tenaud I, Knol AC, Jarrousse V, Quereux G, Khammari A, Dreno B (2005) Induction of toll-like receptors by Propionibacterium acnes. Br J Dermatol 153(6):1105-1113

26. Kim J, Ochoa MT, Krutzik SR, Takeuchi O, Uematsu S, Legaspi AJ, Brightbill HD, Holland D, Cunliffe WJ, Akira S, Sieling PA, Godowski PJ, Modlin RL (2002) Activation of toll-like receptor 2 in acne triggers inflammatory cytokine responses. J Immunol 169(3):1535-1541

27. Fitz-Gibbon S, Tomida S, Chiu BH, Nguyen L, Du C, Liu M, Elashoff D, Erfe MC, Loncaric A, Kim J, Modlin RL, Miller JF, Sodergren E, Craft N, Weinstock GM, Li H (2013) Propionibacterium acnes strain populations in the human skin microbiome associated with acne. J Invest Dermatol 133(9): 2152-2160

28. Tomida S, Nguyen L, Chiu BH, Liu J, Sodergren E, Weinstock GM, Li H (2013) Pan-genome and comparative genome analyses of propionibacterium acnes reveal its genomic diversity in the healthy and diseased human skin microbiome. MBio 4(3):e00003-00013

29. Jahns AC, Eilers H, Ganceviciene R, Alexeyev OA (2015) Propionibacterium species and follicular keratinocyte activation in acneic and normal skin. Brit J Dermatol 172(4):981-987

30. Jarmuda S, O'Reilly N, Zaba R, Jakubowicz O, Szkaradkiewicz A, Kavanagh K (2012) Potential role of Demodex mites and bacteria in the induction of rosacea. J Med Microbiol 61(Pt 11):1504-1510

31. Koller B, Muller-Wiefel AS, Rupec R, Korting HC, Ruzicka T (2011) Chitin modulates innate immune responses of keratinocytes. PLoS One 6(2):e16594

32. Allen HB, Vaze ND, Choi C, Hailu T, Tulbert BH, Cusack CA, Joshi SG (2014) The presence and impact of biofilm-producing staphylococci in atopic dermatitis. JAMA Dermatol 150(3):260 265

33. Fournier B (2012) The function of TLR2 during staphylococcal diseases. Front Cell Infect Microbiol 2:167

34. Niebuhr M, Schorling K, Heratizadeh A, Werfel T (2015) Staphylococcal alpha-toxin induces a functional upregulation of TLR-2 on human peripheral blood monocytes. Exp Dermatol 24(5):381-383

35. Al Mishari MA (1987) Acne vulgaris: Treatment with tetracycline and its effect on bacterial flora. Curr Ther Res Clin Exp 41(3):351355

36. Jakobsson HE, Jernberg C, Andersson AF, Sjolund-Karlsson M, Jansson JK, Engstrand L (2010) Short-term antibiotic treatment has differing long-term impacts on the human throat and gut microbiome. PLoS One 5(3):e9836

37. Relman DA (2012) The human microbiome: ecosystem resilience and health. Nutr Rev 70(Suppl 1):S2-9

38. Leccia MT, Auffret N, Poli F, Claudel JP, Corvec S, Dreno B (2015) Topical acne treatments in Europe and the issue of antimicrobial resistance. J Eur Acad Dermatol Venereol 29:1485-92

39. Chon SY, Doan HQ, Mays RM, Singh SM, Gordon RA, Tyring SK (2012) Antibiotic overuse and resistance in dermatology. Dermatol Ther 25(1):55-69

40. World Health Organization (2001) Global Strategy for Containment of Antimicrobial Resistance. World Health Organization (WHO), Geneva

41. World Health Organization (2014) Antimicrobial resistance. Global report on surveillance: World Health Organization (WHO) 
42. Knoll BM, Mylonakis E (2014) Antibacterial Bioagents Based on Principles of Bacteriophage Biology: An Overview. Clin Infect Dis 58(4):528-534

43. Wells G, Shea B, O'Connell D, Peterson J, Welch V, Losos M, Tugwell P (2012) The Newcastle-Ottawa Scale (NOS) for assessing the quality of nonrandomised studies in meta-analyses, http://www. ohri.ca/programs/clinical_epidemiology/oxford.asp

44. Dowlatshahi EA, Wakkee M, Arends LR, Nijsten T (2014) The prevalence and odds of depressive symptoms and clinical depression in psoriasis patients: a systematic review and meta-analysis. $\mathrm{J}$ Invest Dermatol 134(6):1542-1551

45. McPheeters ML, Kripalani S, Peterson NB, Idowu RT, Jerome RN, Potter SA, Andrews JC (2012) Quality improvement interventions to address health disparities. Closing the quality gap: revisiting the state of the science. Evidence Report No 208 (Prepared by the Vanderbilt University Evidence-based Practice Center under Contract No 290-2007-10065). Rockville, MD: Agency for healthcare research and quality

46. Egger M, Davey Smith G, Schneider M, Minder C (1997) Bias in meta-analysis detected by a simple, graphical test. BMJ 315(7109): 629-634

47. Liberati A, Altman DG, Tetzlaff J, Mulrow C, Gotzsche PC, Ioannidis JP, Clarke M, Devereaux PJ, Kleijnen J, Moher D (2009) The PRISMA statement for reporting systematic reviews and meta-analyses of studies that evaluate healthcare interventions: explanation and elaboration. BMJ 339:b2700

48. Tabatabaei A, Atefi N, Noorbakhsh S (2011) Staphylococcal superantigens in skin biopsy of psoriatic patients: A case control study. Allergy Eur J Allergy Clin Immunol 66:306

49. Tomi NS, Kranke B, Aberer E (2005) Staphylococcal toxins in patients with psoriasis, atopic dermatitis, and erythroderma, and in healthy control subjects. J Am Acad Dermatol 53(1):67-72

50. Ryu JH, Lee J, Son SJ, Won YH, Oh JS (2003) Study of Bacterial Distribution on the Skin of Psoriasis by Tape Method. Korean J Dermatol 41(8):997-1003

51. Brook I, Frazier EH, Yeager JK (1999) Microbiology of infected pustular psoriasis lesions. Int J Dermatol 38(8):579-581

52. Sayama K, Midorikawa K, Hanakawa Y, Sugai M, Hashimoto K (1998) Superantigen production by Staphylococcus aureus in psoriasis. Dermatology 196(2):194-198

53. Noah PW (1990) The role of microorganisms in psoriasis. Semin Dermatol 9(4):269-276

54. Weissmann A, Noble WC (1980) Photochemotherapy of psoriasis: Effects on bacteria and surface lipids in uninvolved skin. Br J Dermatol 102(2):185-193

55. Aly R, Maibach HI, Mandel A (1976) Bacterial flora in psoriasis. Br J Dermatol 95(6):603-606

56. Andersen PS, Larsen LA, Fowler VG Jr, Stegger M, Skov RL, Christensen K (2013) Risk factors for Staphylococcus aureus nasal colonization in Danish middle-aged and elderly twins. Eur J Clin Microbiol Infect Dis 32(10):1321-1326

57. Klein PA, Greene WH, Fuhrer J, Clark RA (1997) Prevalence of methicillin-resistant Staphylococcus aureus in outpatients with psoriasis, atopic dermatitis, or HIV infection. Arch Dermatol 133(11): 1463-1465

58. Singh G, Rao DJ (1978) Bacteriology of psoriatic plaques. Dermatologica 157(1):21-27
59. Ajib R, Janbazian L, Rahal E, Matar GM, Zaynoun S, Kibbi AG, Abdelnoor AM (2005) HLA allele associations and V-beta T-lymphocyte expansions in patients with psoriasis, harboring toxinproducing Staphylococcus aureus. J Biomed Biotechnol 2005(4): 310-315

60. Numata S, Akamatsu H, Akaza N, Yagami A, Nakata S, Matsunaga K (2014) Analysis of facial skin-resident microbiota in Japanese acne patients. Dermatology 228(1):86-92

61. Moon SH, Roh HS, Kim YH, Kim JE, Ko JY, Ro YS (2012) Antibiotic resistance of microbial strains isolated from Korean acne patients. J Dermatol 39(10):833-837

62. Hassanzadeh P, Bahmani M, Mehrabani D (2008) Bacterial resistance to antibiotics in acne vulgaris: An in vitro study. Indian J Dermatol 53(3):122-124

63. Williams RE, Doherty VR, Perkins W, Aitchison TC, Mackie RM (1992) Staphylococcus aureus and intra-nasal mupirocin in patients receiving isotretinoin for acne. Br J Dermatol 126(4):362-366

64. Leyden JJ, McGinley KJ, Foglia AN (1986) Qualitative and quantitative changes in cutaneous bacteria associated with systemic isotretinoin therapy for acne conglobata. J Invest Dermatol 86(4):390-393

65. Batova D, Hadam I (1971) Demonstration of skin microflora in patients with acne vulgaris. Cesk Dermatol 46(5):196-199

66. Ozuguz P, Callioglu EE, Tulaci KG, Kacar SD, Balta I, Asik G, Karatas S, Karaca S (2014) Evaluation of nasal and oropharyngeal flora in patients with acne vulgaris according to treatment options. Int J Dermatol 53(11):1404-1408

67. Basak PY, Cetin ES, Gurses I, Ozseven AG (2013) The effects of systemic isotretinoin and antibiotic therapy on the microbial floras in patients with acne vulgaris. J Eur Acad Dermatol Venereol 27(3): 332-336

68. Toyne H, Webber C, Collignon P, Dwan K, Kljakovic M (2012) Propionibacterium acnes (P. acnes) resistance and antibiotic use in patients attending Australian general practice. Australas J Dermatol 53(2):106-111

69. Khorvash F, Abdi F, Kashani HH, Naeini FF, Narimani T (2012) Staphylococcus aureus in Acne Pathogenesis: A Case-control Study. N Am J Med Sci 4(11):573-576

70. Fanelli M, Kupperman E, Lautenbach E, Edelstein PH, Margolis DJ (2011) Antibiotics, acne, and Staphylococcus aureus colonization. Arch Dermatol 147(8):917-921

71. Levy RM, Huang EY, Roling D, Leyden JJ, Margolis DJ (2003) Effect of antibiotics on the oropharyngeal flora in patients with acne. Arch Dermatol 139(4):467-471

72. Wertheim HF, Melles DC, Vos MC, van Leeuwen W, van Belkum A, Verbrugh HA, Nouwen JL (2005) The role of nasal carriage in Staphylococcus aureus infections. Lancet Infect Dis 5(12):751-762

73. Chehoud C, Rafail S, Tyldsley AS, Seykora JT, Lambris JD, Grice EA (2013) Complement modulates the cutaneous microbiome and inflammatory milieu. Proc Natl Acad Sci U S A 110(37):1506115066

74. Grice EA, Segre JA (2011) The skin microbiome. Nat Rev Microbiol 9(4):244-253

75. Krishna S, Miller LS (2012) Host-pathogen interactions between the skin and Staphylococcus aureus. Curr Opin Microbiol 15(1): 28-35

76. Nakatsuji T, Chiang HI, Jiang SB, Nagarajan H, Zengler K, Gallo RL (2013) The microbiome extends to subepidermal compartments of normal skin. Nat Commun 4:1431 